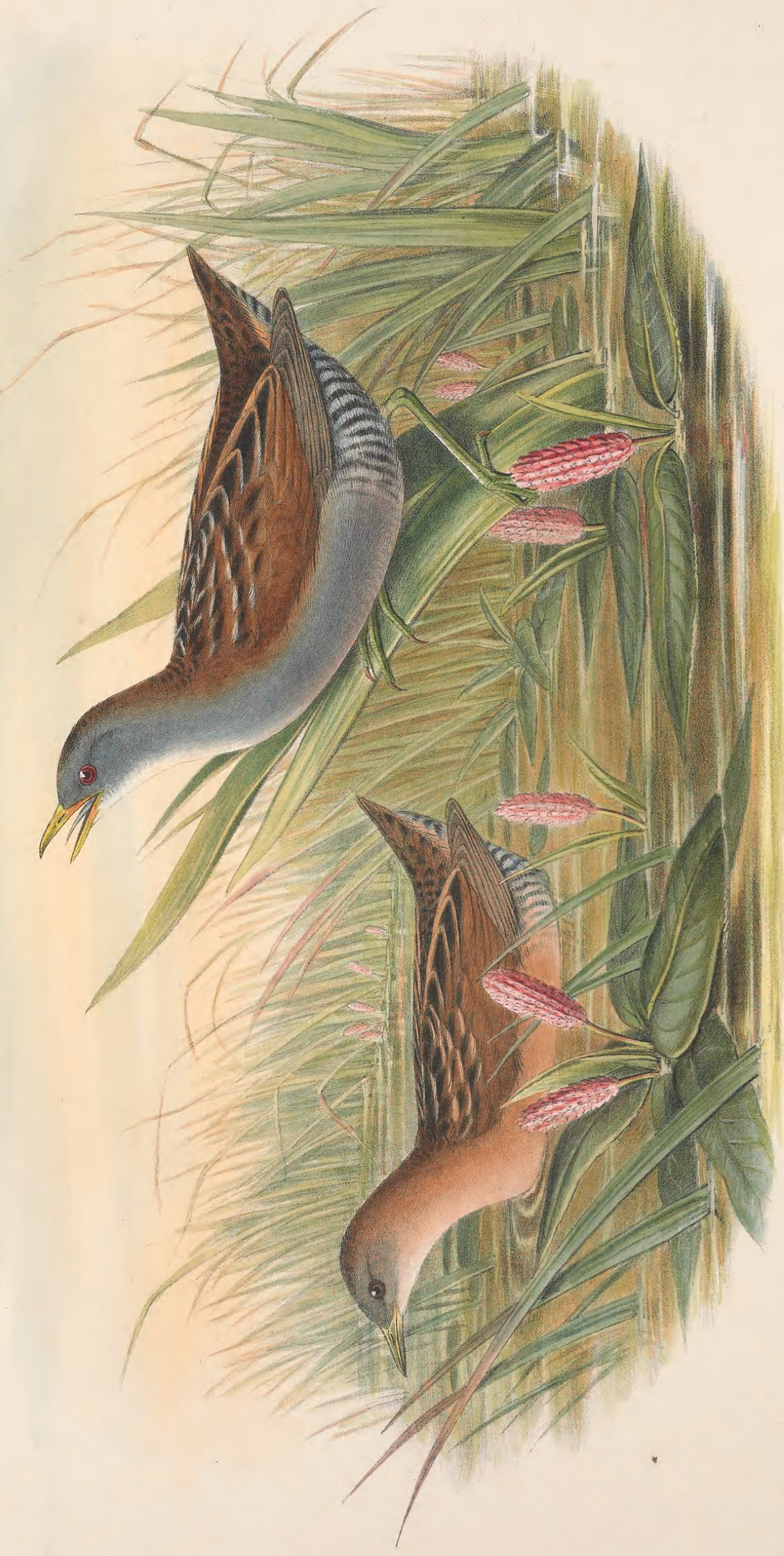




\section{PORZANA MINUTA.}

\section{Olivaceous Crake.}

Rallus minutus, Gmel. edit. Linn. Syst. Nat., tom. i. p. 719.

— parvus, Scop. Ann. Hist. Nat., tom. i. p. 108.

pusillus, Pall. Reisen, tom. iii. p. 700.

Peyrousei, Vieill. Nouv. Dict. d'Hist. Nat., 2nd edit. tom. xxviii. p. 362.

Gallinula pusilla, Temm. Man. d'Orn., 2nd edit. tom. i. p. 690, and tom. iv. p. 440.

- minuta, Mont. Orn. Dict. Suppl.

Foljambei, Mont. Orn. Dict. Suppl., App

Crex pusilla, Selby, Ill. Brit. Orn., vol. ii, p. 185.

— pusillus, De Sélys-Longch. Faune Belge, p. 117.

Zapornia pusilla, Steph. Cont. of Shaw's Gen. Zool., vol. xii. p. 231, pl. 28.

minuta, Bonap. Compt. Rend. de l'Acad. Sci., tom. xliii., Sept. 15 et 22, 1856.

Ortygometra pusilla, Bonap. Geogr. and Comp. List of Birds of Eur. and N. Amer., p. 53. minuta, Blas. List of Birds of Eur., English edit. p. 17.

I $\mathrm{T}$ is probable that this species is far more abundant in the British Islands than is generally supposed, but its retiring habits preclude the possibility of saying whether this be or be not the case. Its natural haunts are great marshes and reed-beds, where, in company with the Bittern and the Bearded Tit, it leads a life of seclusion during the summer months, and rears its young. On the continent of Europe the Olivaceous Crake is more plentiful in the southern and central portions than the north. It is said to be common in Italy, Piedmont, and France, but to be merely an accidental visitor to Holland. In the British Islands also this bird must be considered as an irregular visitor ; for although we have many instances of its occurrence on record, they are "few and far between."

On referring to Yarrell's 'History of British Birds,' we shall find that the names of several of our most celebrated ornithologists are associated with this species. The earliest instance of its occurrence is noticed in the Minute Book of the Linnean Society for 1823, where it is stated that a specimen was shot by John Humphrey, Esq., of Hensley, on the banks of the Yore, on the 6th of May, 1807. But the first example made publicly known was the one described by Colonel Montagu, which had been shot in Devonshire in 1809. The next mentioned is Mr. Foljambe's bird, which was procured from a London poulterer in 1812. This was followed by a specimen obtained by Mr. Plasted, which was shot on the banks of the Thames, near Chelsea, and which is now, I believe, in the collection of Mr. Lombe, near Norwich. In March 1826 a female was caught at Barnwell in Cambridgeshire, which afterwards formed part of Dr. Thackeray's collection, and is now in the Boys' Museum at Eton College. In 1834 an Olivaceous Crake was shot near Yarmouth; in 1835 one was taken alive near Shoreham; in 1836 one was killed near Scarborough; and I am indebted to Mr. J. P. Saville, of Cambridge, for the loan of a very fine adult male, which was captured alive on the 26th of March, 1864, in Chesterton Fen, in that county. Notices like the above comprise the principal part of the information recorded respecting this bird. Of its habits or manners little or nothing is stated. To obtain an accurate knowledge of these, the countries where the bird is more plentiful than it is in England must be visited. There they may be closely observed; here, where it is only an accidental visitor, they cannot be. That, like the Spotted Crake, it is a regular migrant in the parts of the Continent it frequents, there can be little doubt; and I think it probable that those which visit the British Islands may be only stragglers. The structure of all the Crakes is very feeble as compared with that of the Water- and LandRails, and apparently too delicate to admit of their wintering in so rigorous a climate as that of England.

The following remarks by Yarrell comprise all that is known of the bird as observed in this country :"In its food and general habits it very closely resembles the Spotted and other Crakes, but is occasionally seen on higher and more cultivated soils. Montagu truly observes that the babits of the smaller species of Gallinules" or Crakes "are their principal security: they are not only equally capable of diving and concealing their bodies under water, with only the bill above the surface to secure respiration, but run with celerity, and hide themselves amongst the rushes and flags of swampy places, and are with great difficulty roused, even with the assistance of dogs, depending more on concealment in thick cover than upon their wings to avoid danger; hence it is that they are so rarely obtained. The nest is formed of aquatic plants, among rushes; and the eggs are seven or eight in number, of a light olive-brown, spotted with darker brown, are of an oval form, one inch and two lines in length by nine lines and a half in breadth."

M. Bailly states that the Porzana minuta is "very common in summer in the rice-fields of Piedmont, and but little less abundant in the marshes of Savoy, where it is often found in company with the $P$. maruetta 
and P.pygmea, with which latter species it is frequently confounded. It arrives in April or early in May, in considerable numbers. The old birds leave again in August, and the birds of the year some time in September; many of the latter perish when the grass is mown, being knocked down with rods and sticks upon their trying to escape by flight.

"The habits and manners are similar to those of $P$. maruetta. Like that species, it remains concealed among the grass and reeds of the marshes and the borders of lakes and ponds; there it moves gracefully, raising and displaying its tail at every step. It runs with rapidity over the broken reeds. Its food consists of insects, small worms, and aquatic plants. It is very cunning, and is especially noticeable for the subtlety with which it wearies the dog of the sportsman by executing a thousand evolutions with surprising celerity; whence comes the trivial name of Kill-dog bestowed upon it in some localities. Pursued to extremity, it casts itself into the water, swims with ease, and dives at the moment its enemy is about to seize it; or it conceals itself in a tuft of reeds or a bush, and by this means often escapes with impunity. It loves to breed among the reeds and in long and thick grass, frequently in small companies, of its own species or of $P$. pygmaa. The female lays her eggs on an inartificially constructed platform of decayed leaves or stalks of marsh-plants, slightly elevated above the water. The eggs are from seven to ten in number, of a yellowisholive colour, finely spotted with a darker tint. The young, when hatched, are clothed with a black down, glossed with green on the head and part of the neck, and immediately follow the mother, whom they never quit until they begin to fly. The flesh of this Crake is succulent during autumn, and superior in delicacy to that of the $P$. maruettu."

Although little difference is observable in the colouring of the sexes when adult, the young differ considerably from their parents, and very much resemble the young of the Moorhen, all the under surface being lighter than in the adults, and destitute of the blue-grey tint which characterizes them in after-life. The accompanying Plate will show these differences more clearly than the most minute description. 


\section{$2 \mathrm{BHL}$ Biodiversity Heritage Library}

Gould, John. 1873. "Olivaceous Crake, Porzana minuta [PI. 90]." The birds of Great Britain 4, -. https://doi.org/10.5962/p.324044.

View This Item Online: https://www.biodiversitylibrary.org/item/221609

DOI: https://doi.org/10.5962/p.324044

Permalink: https://www.biodiversitylibrary.org/partpdf/324044

\section{Holding Institution}

Smithsonian Libraries

\section{Sponsored by}

Biodiversity Heritage Library

\section{Copyright \& Reuse}

Copyright Status: Public domain. The BHL considers that this work is no longer under copyright protection.

This document was created from content at the Biodiversity Heritage Library, the world's largest open access digital library for biodiversity literature and archives. Visit BHL at https://www.biodiversitylibrary.org. 